\title{
DESIGNATION OF A TYPE-SPECIES FOR \\ CYCLOGASTER MACQUART, 1834, AND THE \\ RESULTING SYNONYMY (DIPTERA: STRATIOMYIDAE)*
}

\author{
By Norman E. WoOdLey \\ Museum of Comparative Zoology \\ Harvard University \\ Cambridge, Massachusetts 02138
}

The generic name Cyclogaster Macquart (1834) has been used in combination with specific names for taxa of Stratiomyidae from diverse regions of the world. It has remained more or less in synonymy with Lasiopa Brulle (1832) since the time of Brauer (1882), although Pleske (1901: 336) described Cyclogaster caucasica (Palaearctic) and Hutton (1901: 10) described C. peregrinus from New Zealand after Brauer's work appeared. Kertész (1908) also considered the two names synonymous, and placed 15 species in Lasiopa. These species are placed in at least five genera at the present time.

The purpose of this paper is to designate a type-species for $C y c l o-$ gaster, which to my knowledge has never been done, in order to stabilize the generic synonymy as it is presently used by workers in the Stratiomyidae. A brief review of the history of the name Cyclogaster and generic names associated with it is necessary to understand the situation fully.

Macquart (1834: 256) first proposed the name Cyclogaster in the Diptera, and included in that taxon two species, Nemotelus villosus Fabricius (1794: 270; Palaearctic) and Stratiomys atrata Fabricius (1805: 83; Neotropical). No single type-species was designated.

The generic name Inermyia Bigot $(1856: 82,63)$ was proposed for the South African species Stratiomys edentula Wiedemann (1824: 29). Gerstaecker (1857: 322) and Loew (1860: 7) both considered Stratiomys edentula a member of Cyclogaster Macquart and Kertész (1908: 30) listed Inermyia as a synonym with a query. Lindner (1972: 32) considered the species to be congeneric with the true, Palaearctic Lasiopa, and it is listed as such by James (1980: 260).

Kirkaldy (1910: 8) noted that the name Cyclogaster was preoccupied in zoology by Cyclogaster Gronovius, in the fishes (this name will be discussed in more detail below). He proposed a replacement name for the name in the Diptera, Neotropicalias. No reference was made to any specific names, although one might infer he was think- 
ing of the Neotropical species that Macquart had originally included in Cyclogaster.

Enderlein (1914: 579, 615), without any reference to Kirkaldy (1910), but evidently realizing that the two species originally included in Cyclogaster were not congeneric, proposed the name Labocerina for Stratiomys atrata Fabricius. In his paper, the new name was spelled Labocerina twice (pp. 579, 615), and "Labacerino" once (p. 615), and has subsequently been spelled "Labocerino" by James (1940: 124). These latter two spellings were regarded as errors by James (1973: 26.29). In the same paper, Enderlein considered Cyclogaster a synonym of Lasiopa.

The name Cyclogaster Gronovius (1756: 9; 1760: 265; 1763: 55) was in dispute, as were all of his generic names, because many authors felt his work was not truly binomial. His Cyclogaster was first published in 1756, but this is pre-Linnean. The 1760 work is clearly not binomial, although this is the date of the name usually found in zoological nomenclators, being the first post-Linnean publication of it. In 1954, the International Commission on Zoological Nomenclature formally ruled that Gronovius' 1763 work, as well as an index of it subsequently published by Meuschen, be placed on the Official Index of Rejected and Invalid Works in Zoological Nomenclature. Thus Macquart's Cyclogaster became the earliest valid use of the name in zoology.

Lindner (1958: 432), while discussing "Cyclogaster" peregrinus Hutton from New Zealand, recounted most of the above briefly, and noted that no type-species had been designated for Cyclogaster Macquart, but was apparently not aware of the I. C. Z. N. ruling. He also mentioned that Nemotelus villosus Fabricius was the typespecies of Lasiopa (as had Enderlein, 1914: 613, and several other authors), which is erroneous, as the only species name associated with Lasiopa in Brullé's original description was Lasiopa peleteria, which was described concurrently and is still regarded as a valid species.

As I interpret the situation, a type-species designation is necessary for Cyclogaster Macquart in order to stabilize generic synonymy, and as far as I am aware, this has never been done. In order to preserve the presently accepted generic synonymies, I hereby designate Nemotelus villosus Fabricius, originally included in Cyclogaster by Macquart, as type-species for that genus. The following 
synonymy for Lasiopa, the senior generic name, results:

Lasiopa Brullé, 1832: 307. Type-species: L. peleteria Brullé, 1832: 308 (by monotypy). Cyclogaster Macquart, 1834: 256. Type-species: Nemotelus villosus Fabricius, 1794: 270 (by present designation).

Inermyia Bigot, 1856: 82. Type-species: Stratiomy's edentula Wiedemann, 1824: 29 (by original designation, op. cit.:63).

Neotropicalias Kirkaldy, 1910: 8; replacement name for Cy'clogaster Macquart, 1834, nec Gronovius, 1763. Type-species: Nemotelus villosus Fabricius, 1794: 270 (by autotypy).

The above type-species designation thus stabilizes the long-used synonymy of Cyclogaster with Lasiopa, while retaining the name Labocerina Enderlein for the Neotropical Stratiomys atrata Fabricius. The name Neotropicalias Kirkaldy became an unnecessary, and therefore invalid, replacement name when Cyclogaster Gronovius was rejected by the I. C. Z. N. ruling.

\section{ACKNOWLEDGMENTS}

I wish to thank Curtis W. Sabrosky and Margaret K. Thayer for critically reading the manuscript.

\section{Literature Cited}

Bigot, J. M. F. 1856. Essai d'une classification générale et synoptique de l'ordre des Insectes Diptères. (4 ${ }^{\mathrm{e}}$ Mémoire.) Ann. Soc. Ent. Fr. (3)4: 51-91.

Brauer, F. 1882. Zweiflügler des Kaiserlichen Museums zu Wien. II. Denkschr. Akad. Wiss. Wien 44(1): 59-110.

Brullé, G. A. 1832. IV ${ }^{\mathrm{e}}$ Classe. Insectes. Pp. 64-395, in Bory de SaintVincent (ed.), Expédition scientifique de Morée. Section des sciences physiques 3(1) (Zool. 2), Paris. $400 \mathrm{pp.}$

Enderlein, G. 1914. Dipterologische Studien. IX. Zur Kenntnis der Stratiomyiiden mit 3ästiger Media und ihre Grüppierung. A. Formen, bei denen der I. Cubitalast mit der Discoidalzelle durch Querader verbunden ist oder sie nur in einem Punkte berührt (Subfamilien: Geosarginae, Analcocerinae, Stratiomyiinae). Zool. Anz. 43: 577-615.

Fabricius, J. C. 1794. Entomologia systematica emendata et aucta. Secundum classes, ordines, genera, species adjectis synonimis, locis, observationibus, descriptionibus. Vol. 4. Hafniae. $472 \mathrm{pp}$.

1805. Systema antliatorum secundum ordines, genera, species adiectis synonymis, locus, observationibus, descriptionibus. Brunsvigae. $372+30 \mathrm{pp}$.

Gerstaecker, A. 1857. Beitrag zur Kenntniss exotischer Stratiomyiden. Linn. Ent. 11: $261-350$. 
Gronovius, L. T. 1756. Musei Ichthyologici tomus secundus sistens Piscium indigenorum \& nonnullorum exoticorum, quorum maxima pars in Museo Laurentii Theodori Gronovii, J. U. D. adservatur, nec non quorumdam in aliis Museis observatorum descriptiones. Accedunt nonnullorum exoticorum Piscium icones aeri incisae, et Amphibiorum Animalium Historia Zoologica. Lugduni Batavorum. [i-viii] + 1-88 pp.

1760. Animalium in Belgio Habitantium centuria prima. Acta Helvetica 4: $243-270$.

1763. Zoophylacii Gronoviani Fasciculus primus exhibens Animalia Quadrupeda, Amphibia atque Pisces, quae in Museo suo adservat, rite examinavit, systematice, disposuit, descripsit, atque iconibus illustravit. Lugduni Batavorum. [i-iv]+1-136 pp.

Hutton, F. W. 1901. Synopsis of the Diptera brachycera of New Zealand. Trans. Proc. New Zealand Inst. 33: 1-95.

InTERnational Commission on Zoological Nomenclature. 1954. Opinion 261. Rejection for nomenclatural purposes of the Index to the Zoophylacium Gronovianum of Gronovius prepared by Meuschen (F. C.) and published in 1781. Opin. Decl. Int. Comm. Zool. Nom. 5: 281-296.

JAMES, M. T. 1940. Studies in Neotropical Stratiomyidae (Diptera). IV. The genera related to Cyphomyia Wiedemann. Revista Ent. 11: 119-149.

1973. Family Stratiomyidae, No. 26, in A catalog of the Diptera of the Americas south of the United States. São Paulo. $95 \mathrm{pp}$.

1980. 20. Family Stratiomyidae, pp. 253-274, in Crosskey, R. W., ed. Catalogue of the Diptera of the Afrotropical Region. London. $1437 \mathrm{pp}$.

KerTész, K. 1908. Catalogus Dipterorum. Volumen III. Stratiomyiidae, Erinnidae, Coenomyiidae, Tabanidae, Pantophthalmidae, Rhagionidae. Budapestini. $366 \mathrm{pp}$.

KirKaldy, G. W. 1910. On some preoccupied generic names in insects. Canad. Ent. 42: 8 .

LINDNER, E. 1958. Ü ber einige neuseeländische Stratiomyiiden Osten-Sackens im Deutschen Entomologischen Institut in Berlin. Beitr. Ent. 8: 431-437.

1972. Uber einige Stratiomyidae des Transvaal Museums (Diptera: Brachycera). Ann. Transvaal Mus. 28: 27-34.

LoEw, H. 1860. Die Dipteren-Fauna Südafrika's. Erste Abtheilung. Abh. Naturw. Ver. Sachsen u. Thüringen in Halle 2: $57-402$.

Macquart, J. 1834. Histoire naturelle des Insectes. Diptères. Vol. I. Paris. $578 \mathrm{pp}$.

Pleske, T. 1901. Studien über palaearktische Stratiomyiden. I. Die Gattung Crclogaster Macqu. Sitzungsber. Naturf. Ges. Univ. Jurjeff (Dorpat) 12: 335-340.

Wiedemann, C. R. W. 1824. Munus rectoris in Academia Christiana Albertina aditurus Analecta entomologica ex Museo Regio Havniensi maxime congesta profert iconibusque illustrat. Kiliae. $60 \mathrm{pp}$. 

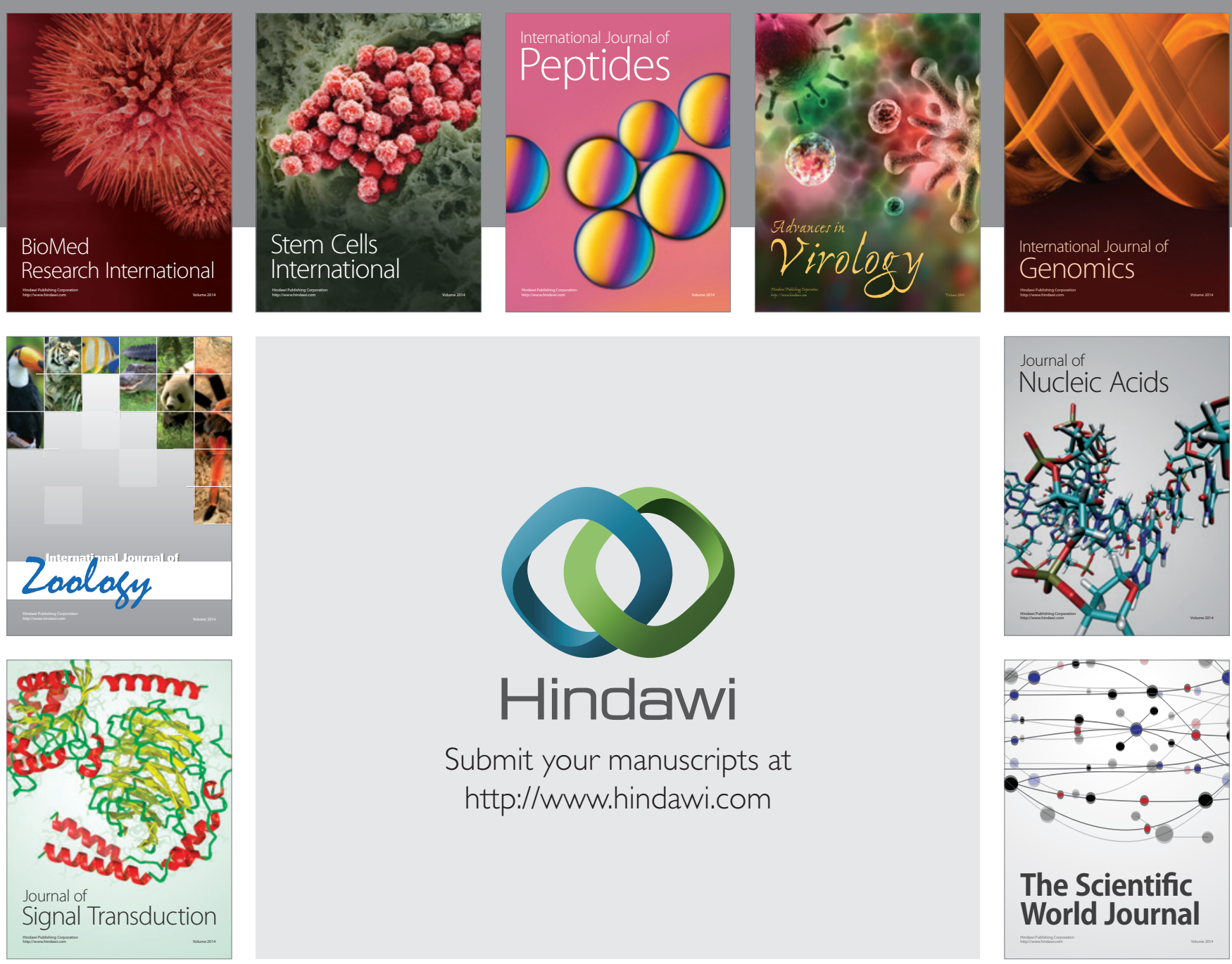

Submit your manuscripts at

http://www.hindawi.com
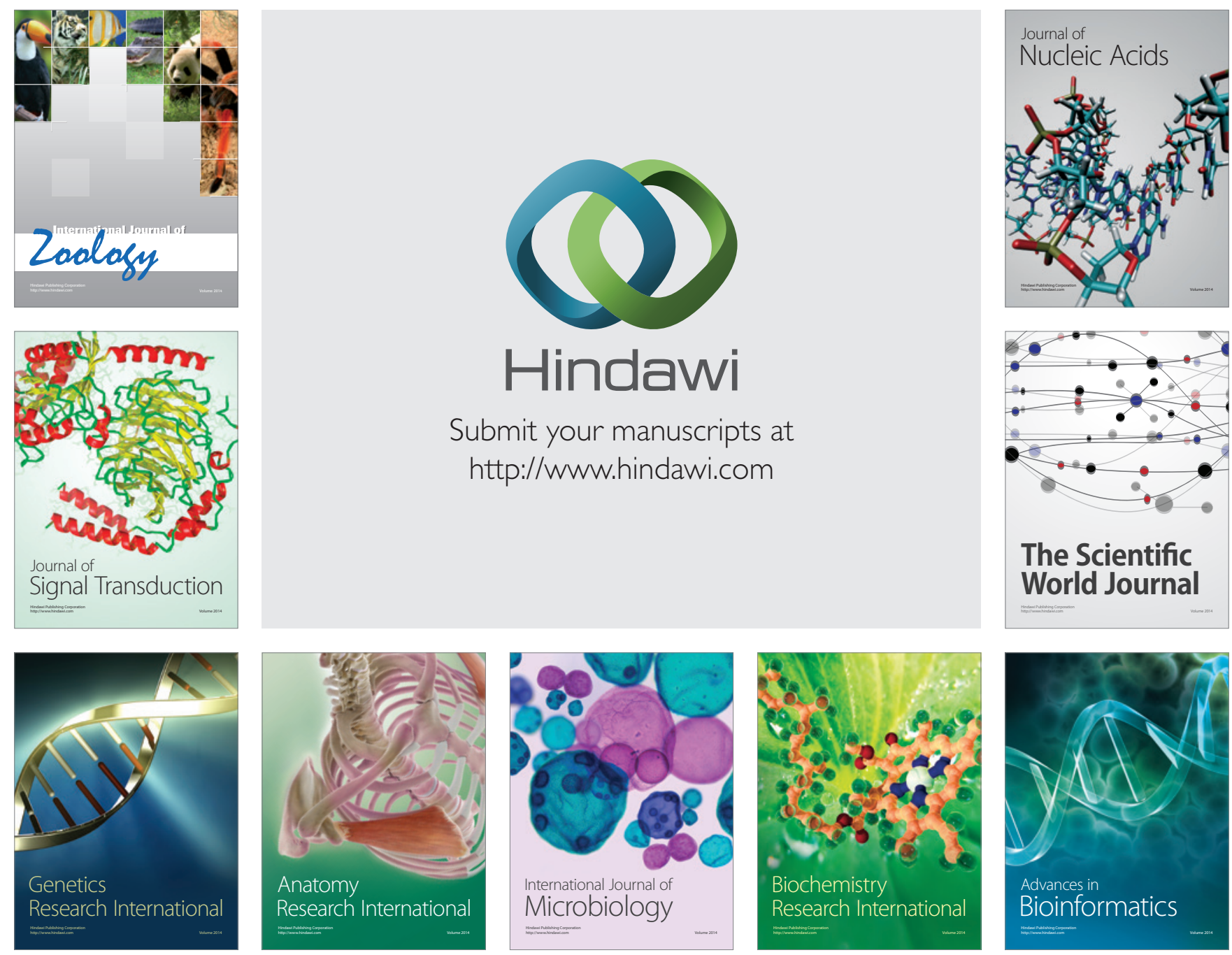

The Scientific World Journal
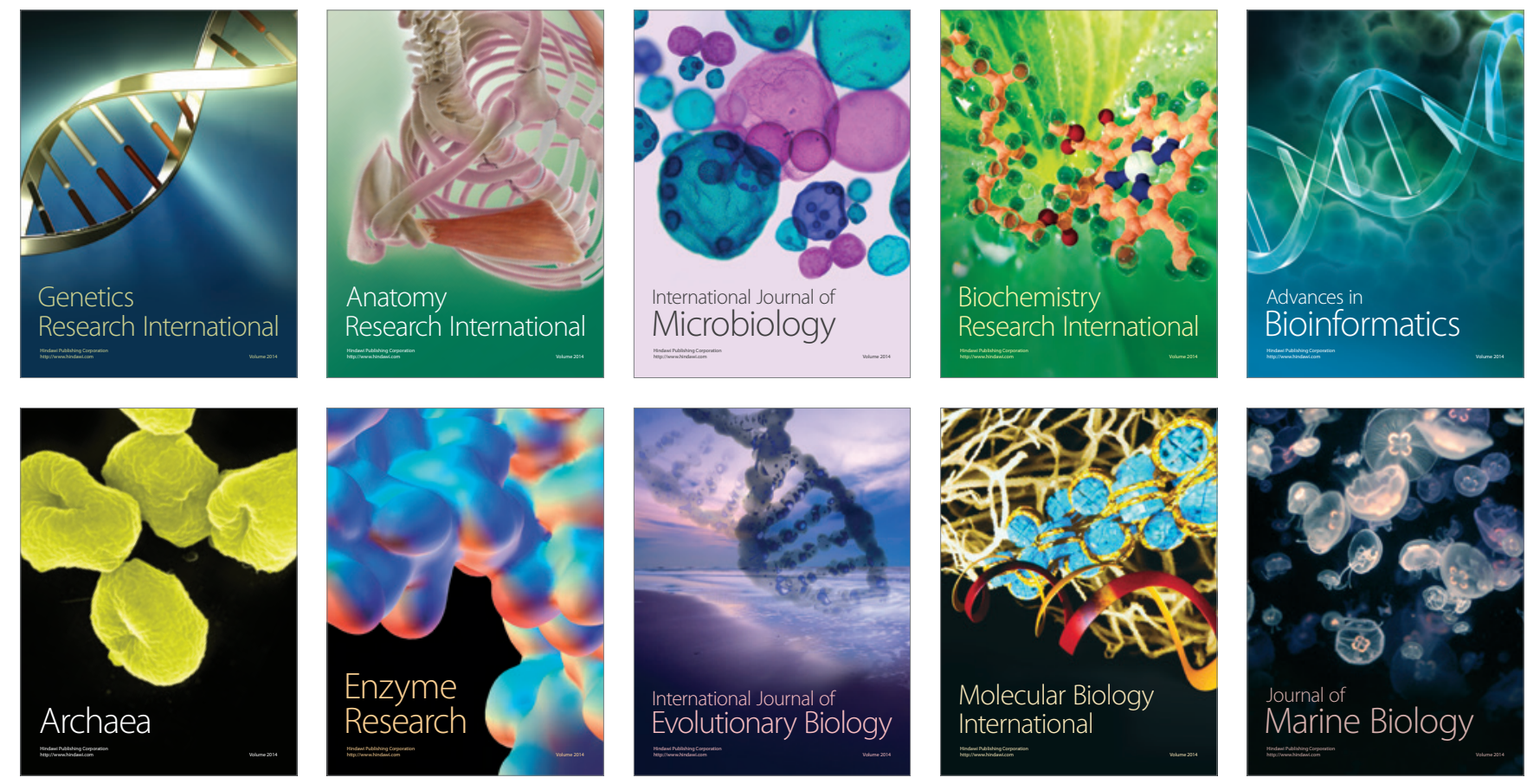